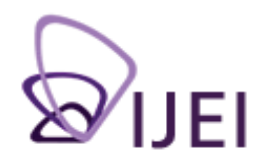

International Journal for Educational Integrity

\title{
YouTube: An international platform for sharing methods of cheating
}

\author{
Christopher M. Seitz \\ Department of Public Health Education, \\ University of Carolina, Greensboro, USA. \\ cmseitz@uncg.edu \\ Muhsin Michael Orsini \\ Department of Public Health Education, \\ University of Carolina, Greensboro, USA. \\ mmorsini@uncg.edu
}

\author{
Meredith R. Gringle \\ Department of Public Health Education, \\ University of Carolina, Greensboro, USA. \\ mrgringl@uncg.edu
}

Keywords: international, instructional, cheating, video, online

\begin{abstract}
This study investigated the video sharing website www.youtube.com for the presence of instructional videos that teach students how to cheat on academic work. Videos were analysed to determine the methods of cheating, the popularity of the videos, the demographics of viewers and those uploading the videos, and the opinions of viewers after watching these types of videos. A total of 43 videos were included in this study. Those featured in the videos taught viewers how to cheat on exams, homework, and written assignments using modern and traditional technologies. The far majority of those featured in the videos, and their viewers, were males within the age range of those who attend middle school, high school, and college. Videos were watched by people from several different nations, including the United States (US), Canada, Australia, India, and the United Kingdom (UK). The study's results suggest that instructional cheating videos are popular among students around the world. Positive viewer feedback indicates that the videos have educated and motivated students to put the methods of cheating found in the videos to use. Educators should consider YouTube as a resource in order to become familiar with various methods of cheating.

\section{Introduction}

Cheating is prevalent in educational systems throughout the world. In the US alone, it is estimated that a third of students in elementary school and over half of students in high school and college have participated in some sort of dishonest academic work (Schmelkin, Gilbert, Spencer, Pincus, \& Silva, 2008). Studies show that other nations also experience problems with academic dishonesty, including Poland (Lupton, Chapman, \& Weiss, 2000), Australia (Brimble \& Stevenson-Clarke, 2005), Taiwan (Lin \& Wen, 2007), Croatia (Hrabak et al., 2004), the UK (Franklyn-Stokes \& Newstead, 1995) and so on.

The International Journal for Educational Integrity is available online at: http://www.ojs.unisa.edu.au/journals/index.php//JEI/




Although cheating has been studied for decades (McCabe, Treviño, \& Butterfield, 2001), there remains a lack of formal research regarding where students learn how to engage in various methods of cheating. However, it has been suggested by McCabe and Treviño (1993) that students learn how to cheat by observing the behaviours of their peers. More recently, anecdotal reports indicate that students upload instructional videos on YouTube for others to observe and learn how to cheat on exams (Foster, 2008; Orsini \& Gringle, 2009). YouTube is a website that allows its members to post videos for people to watch (YouTube, 2011a) and to share comments about the videos in an online forum (YouTube, 2011b). YouTube is the third most viewed website on the internet (Alexa, 2011), with 24 hours of video being uploaded every minute and two billion videos watched everyday across the world (YouTube, 2011c). It is not surprising that students would turn to YouTube videos to learn methods of cheating, as the internet has become a common place for students to search for answers to homework and to plagiarise text (Harper, 2006; Lathrop \& Foss, 2000; Kennedy, Nowak, Raghuraman, Thomas, \& Davis, 2000; Szabo \& Underwood, 2004).

Given that students are using YouTube to learn new cheating techniques, the authors of this paper designed a content analysis of the videos related to cheating on YouTube in order to gain a deeper understanding of the presence and characteristics of instructional cheating videos posted on the website. Specifically, the study aimed to answer the following research questions: (1) What methods of cheating are depicted within the videos? (2) How popular are instructional cheating videos on YouTube? (3) What are the demographics of those who post and view the videos? (4) What are the opinions of viewers towards these types of videos?

\section{Methods}

\section{Data collection}

On January 28, 2011, YouTube (www.youtube.com) was searched using the following terms in various combinations: how to, cheat, quiz, test, exam, homework, paper, essay. These terms were used to find video content related to academic dishonesty in typical areas of scholarly work, such as taking tests, completing homework assignments, and writing papers. Videos resulting from each search term were initially screened for study inclusion factors. Videos were included in the study only if they met the following criteria: the video content was instructional and the primary focus of the video was cheating. The viewer-posted comments from each video were copied and pasted into a document for analysis. Demographic information of viewers was obtained by clicking on the YouTube videos' "show video statistics" button. This data includes statistics on viewers' sex, self-reported age ranges (as defined by YouTube, e.g. 13-17, 18-24, 25-34), and nationality. This information pertains only to registered YouTube members who have watched the videos.

\section{Data analysis}

Videos that met the study's inclusion criteria and their respective viewer-posted comments were analysed for the following variables: the method of academic dishonesty, how many times the videos were viewed in the study's 30-day period (January 28, 2011 to February 26, 2011), demographic information of those who post and those who view the videos, and viewer response to the videos, as shown through viewer-posted comments. Demographic information of those featured in the videos was based upon the estimation of the researchers. The viewer-posted comments were analysed as being positive, negative, or neutral/irrelevant. Comments were categorised as being positive if the comments were encouraging, reflected admiration of the person in the video or of cheating in general, expressed a desire to use the method of cheating in the future, or discussed cheating in a positive tone. Viewerposted comments were categorised as negative if the comments were critical of the method of cheating or of cheating in general. Comments were categorised as being 
neutral/irrelevant if they neither approved nor disapproved of cheating or if the comments were unrelated to the video.

\section{Results}

\section{Number of videos and "views"}

There were a total of 43 videos that met inclusion criteria. On January 28, 2011, the number of video "views" ranged from 16 to $6,270,652(M=278,788, S D=986,425$, $M d n=7,893$ ) with a combined total views of $11,987,891$. The range of views increased at the 30-day follow-up by 37 to $6,365,384(M=284,445, S D=1,001,920$, $M d n=8,163)$ and had a combined total views of $12,231,127$. On average, each video was viewed 5,657 times $(S D=15,822, M d n=342)$ within the study's 30 -day period.

\section{Demographic information}

Video content was analysed for basic demographic information (sex and age) of those featured in the instructional cheating videos. Of the videos, $34(79 \%)$ featured males, $2(5 \%)$ featured females, and $7(16 \%)$ did not physically show the person teaching a cheating method, thus not allowing for the person's sex to be determined. Within the sample, it was estimated that $15(44 \%)$ of the videos featured people who were college-aged, 11 (32\%) high school-aged, 10 (29\%) middle school-aged, and 7 (16\%) did not physically show the person teaching a cheating method, thus not allowing for the person's age to be estimated.

YouTube's "show video statistics" button allowed the researchers to collect demographic information about YouTube members who have watched the video. In our study's sample, the audience who most often viewed the instructional cheating videos included males aged 13 to 17 , males aged 18 to 24 , males aged 25 to 34 , and females aged 13 to 17 . The study's sample of instructional cheating videos was watched in nearly every nation in the world; however, the most viewers were located in the US, Canada, Australia, India and the UK.

\section{Methods of cheating}

The sample of instructional videos described methods for cheating on exams, homework and writing assignments. After viewing all of the videos, the authors categorised the methods for cheating as being either high technical (Table 1) or low technical (Table 2). High technical cheating methods used some sort of modern technology to aid in the cheating process. For instance, the most viewed high tech cheating method for an exam involved removing and scanning the label of a soda bottle. Next, computer software, such as Adobe Photoshop, is used to digitally erase the nutritional information from the label and replace the information with notes and formulas needed for an exam (Figures 1 and 2). The modified label is then color printed, attached to the soda bottle, and used as a reference by the student during the exam. Another example of a high tech cheating method discovered in this study is to use Microsoft Word as a tool to dishonestly, and subtly, lengthen an assigned paper. In this cheating method, students use Microsoft Word's "Replace" function in order to replace a paper's periods with periods of a larger font. Since teachers often have stipulations about an assigned paper's margins, spacing, font, and font size, students may have difficulty lengthening a paper by modifying these without a teacher noticing an alteration to the paper's specifications. However, by changing a paper's periods from a 12-point font to a 14-point font, a paper can be considerably lengthened without making obvious changes to a paper's margins, spacing, text font, and text font size (Figure 3).

Low technical cheating methods in the study's sample of videos did not require the aid of modern technology. For example, the most viewed low tech cheating method featured in the videos was to attach a small paper scroll to the ink cartridge of a ballpoint pen. The scroll slides out of the pen's shell through a cut that is made near 
the end of the pen. During the exam, the student can read notes from the scroll. However, if a teacher comes near, the student may slide the scroll back into the pen by manually twisting the ink cartridge that holds the scroll (Figure 4).

Table 1:

High-tech methods of cheating as shown through YouTube

\begin{tabular}{|c|c|c|}
\hline Cheating method & $\begin{array}{l}\text { Scholarly } \\
\text { activity }\end{array}$ & Description of method \\
\hline $\begin{array}{l}\text { Information on } \\
\text { scanned nutritional } \\
\text { label of soda }\end{array}$ & Exam & $\begin{array}{l}\text { Remove the label from a soda bottle. Digitally scan } \\
\text { the label. Use software to erase the nutritional } \\
\text { information and replace the information with notes } \\
\text { and formulas needed for an exam. Print the } \\
\text { modified label, attach it to the soda bottle, and use } \\
\text { as a reference during the exam. }\end{array}$ \\
\hline $\begin{array}{l}\text { Notes as an iPod } \\
\text { song }\end{array}$ & Exam & $\begin{array}{l}\text { Digitally record yourself speak the notes needed for } \\
\text { an exam. Store the recording as a song in your } \\
\text { iPod. Attach the iPod to your upper arm, cover it } \\
\text { with long sleeves, connect the earphones to your } \\
\text { ears, cover the earphones with long hair. Play the } \\
\text { song during the exam and listen to the notes. }\end{array}$ \\
\hline $\begin{array}{l}\text { Notes on graphing } \\
\text { calculator }\end{array}$ & Exam & $\begin{array}{l}\text { Store notes into graphing calculator (TI-83/84) to be } \\
\text { used during a test. }\end{array}$ \\
\hline Notes on cell phone & Exam & Store notes on a cell phone to be used during a test. \\
\hline $\begin{array}{l}\text { Communicate with } \\
\text { others with a spy } \\
\text { watch }\end{array}$ & Exam & $\begin{array}{l}\text { Purchase a "spy watch" that allows you to } \\
\text { communicate with others. }\end{array}$ \\
\hline $\begin{array}{l}\text { Insert an iPod into a } \\
\text { graphing calculator }\end{array}$ & Exam & $\begin{array}{l}\text { Remove the outer shell of a graphic calculator. } \\
\text { Place a PDA inside of the shell. Store notes into the } \\
\text { PDA and use them during the exam. }\end{array}$ \\
\hline Ultraviolet pen & Exam & $\begin{array}{l}\text { Purchase an ultraviolet pen. Take invisible notes on } \\
\text { a piece of scratch paper. Use the pen to see the } \\
\text { invisible notes during an exam. }\end{array}$ \\
\hline Notes on tape & Exam & $\begin{array}{l}\text { Press a piece of scotch tape on notes printed from } \\
\text { an ink jet printer. Put warm water over the tape and } \\
\text { slowly remove from the paper. The ink from the } \\
\text { paper will transfer to the tape. Place the tape with } \\
\text { notes on an object that can be used during the test, } \\
\text { such as a pencil, pen, or beverage. }\end{array}$ \\
\hline $\begin{array}{l}\text { Math homework } \\
\text { websites }\end{array}$ & $\begin{array}{l}\text { Math } \\
\text { homework }\end{array}$ & $\begin{array}{l}\text { Purchase a subscription to the websites } \\
\text { hotmath.com and mathway.com in order to have } \\
\text { access to the solutions for math problems from any } \\
\text { textbook. }\end{array}$ \\
\hline Replace periods & Paper & $\begin{array}{l}\text { Use the "Replace" function in Microsoft Word to } \\
\text { replace 12-point periods with 14-point periods. This } \\
\text { will lengthen a paper without a teacher noticing. }\end{array}$ \\
\hline
\end{tabular}


Table 2:

Low-tech methods of cheating as shown through YouTube

\begin{tabular}{|l|l|l|}
\hline Cheating method & $\begin{array}{l}\text { Scholarly } \\
\text { activity }\end{array}$ & Description of method \\
\hline Notes on rubber band & Exam & $\begin{array}{l}\text { Stretch a rubber band around a textbook and write } \\
\text { notes on the stretched out rubber band. When the } \\
\text { rubber hand is taken off the textbook, the notes } \\
\text { shrink and become illegible. The notes can be } \\
\text { looked at during a test by quickly stretching out the } \\
\text { rubber band while on your wrist. }\end{array}$ \\
\hline Notes on a pen scroll & Exam & $\begin{array}{l}\text { Attach a small scroll to the ink cartridge of a ball point } \\
\text { pen. The scroll slides out of the pen's shell through a } \\
\text { slice that is made near the end of the pen. You can } \\
\text { read the scroll during the exam and hide the scroll } \\
\text { back into the pen by twisting the ink cartridge. }\end{array}$ \\
\hline $\begin{array}{l}\text { Notes inside clear } \\
\text { pens/pencils }\end{array}$ & Exam & $\begin{array}{l}\text { Place notes inside of pens/pencils that are } \\
\text { transparent. }\end{array}$ \\
\hline $\begin{array}{l}\text { Notes inside pen/ } \\
\text { pencil "window" }\end{array}$ & Exam & $\begin{array}{l}\text { Create or purchase a mechanical pen/pencil that has } \\
\text { a transparent "window" on its side. Every time the } \\
\text { end of the pen/pencil is pushed down, the inside of } \\
\text { the pen rotates to expose different notes through the } \\
\text { pen/pencil's window. }\end{array}$ \\
\hline label watects & Exam & $\begin{array}{l}\text { Place notes on or inside of objects that can be taken } \\
\text { into an exam, such as: wrappers (gum/cough drops) } \\
\text { inside of calculator covers, pen caps, wrist bands, } \\
\text { bottom of shoes, eraser, and band aids. }\end{array}$ \\
\hline $\begin{array}{l}\text { Peel label off a bottle of water. Write notes on the } \\
\text { inside of the label. Reattach the label. Look at the } \\
\text { notes through the bottle. The angle of the top of the } \\
\text { bottle with the water will magnify the notes. }\end{array}$ \\
\hline
\end{tabular}

\begin{tabular}{|c|c|c|}
\hline $\begin{array}{l}\text { Nutrition Facts } \\
\text { Serving Size } \\
\text { Servings per Container }\end{array}$ & $\begin{array}{l}\text { Standard Serving } \\
10 \mathrm{fl} \text { oz }(240 \mathrm{~mL}) \\
2.0\end{array}$ & $\begin{array}{l}\text { This Package } \\
20 \mathrm{fl} \text { oz }(590 \mathrm{~mL})\end{array}$ \\
\hline Amount per Serving & \%DV ${ }^{*}$ & $\% \mathrm{DV}^{*}$ \\
\hline Calories & 100 & 240 \\
\hline Total Fat & $0 \%$ & $0 \%$ \\
\hline Sodium & $34 \mathrm{mg}$ & $73 \mathrm{mg}$ \\
\hline Total Carbohydrate & $21 \mathrm{~g}$ & $20 \%$ \\
\hline Sugars & $21 \mathrm{~g}$ & $65 \mathrm{~g}$ \\
\hline Protein & $0 \mathrm{~g}$ & $0 \mathrm{~g}$ \\
\hline \multicolumn{3}{|c|}{$\begin{array}{l}\text { Not a significant source of calories from fat, saturated fat, cholesterol, die- } \\
\text { tary fiber, vitamin A, C, D, calcium, and iron }\end{array}$} \\
\hline \multicolumn{3}{|c|}{${ }^{*}$ Percent Daily Values (DV) are based on a 2,500 calorie diet } \\
\hline
\end{tabular}

Figure 1. Normal nutritional label 


\begin{tabular}{|c|c|c|}
\hline $\begin{array}{l}\text { Nutrition Facts } \\
\text { Serving Size } \\
\text { Servings per Cheater }\end{array}$ & $\begin{array}{l}\text { StandardCheating } \\
10 \mathrm{fl} \text { oz }(\mathrm{mL}) \\
1.0\end{array}$ & $\begin{array}{l}\text { This Exam } \\
20 \mathrm{fl} \mathrm{oz}(590 \mathrm{~mL})\end{array}$ \\
\hline Amount per Dishonesty & $\% \mathrm{DV}^{*}$ & $\% \mathrm{DV}^{*}$ \\
\hline Calories & 100 & 240 \\
\hline Total Fat & $0 \%$ & $0 \%$ \\
\hline Sodium & $34 \mathrm{mg}$ & 14Mar $1879 \%$ \\
\hline 1921 Nobel Prize & $\mathrm{E}=\mathrm{MC}^{2}$ & 18Apr $1955 \%$ \\
\hline Sugars & $21 g$ & $65 g$ \\
\hline Protein & $\mathrm{Og}$ & $0 \mathrm{~g}$ \\
\hline \multicolumn{3}{|c|}{$\begin{array}{l}\text { Not a significant source of albert einstein, calories from fat, saturated fat, } \\
\text { and theory and relativity }\end{array}$} \\
\hline
\end{tabular}

Figure 2. Modified nutritional label

Cheater. Cheater. Pumpkin eater. Cheater. Cheater. Pumpkin eater.

Figure 3. 12-point vs. 14-point sized periods in Times New Roman
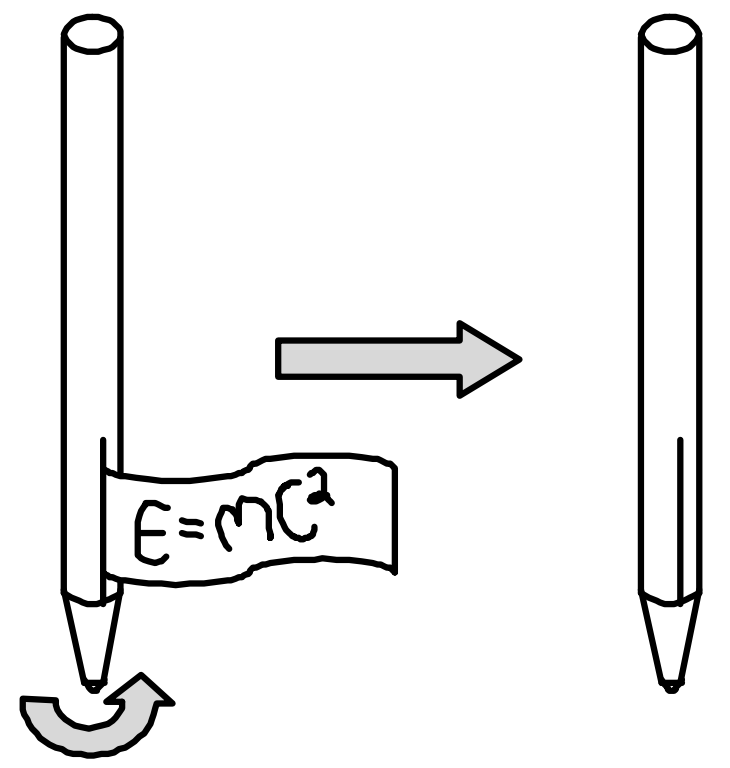

Figure 4. Pen that has been cut and has a scroll attached to ink cartridge

\section{Viewer-posted comments}

When posting a video, YouTube members have the option to either allow or not allow viewers to share comments about the video in a discussion board format. In our study, one of the videos did not allow viewers to make comments. Of the remaining 42 videos, there were a total of 88,998 viewer-posted comments. In all, $28,518(32 \%)$ 
of the total comments were classified by the authors as being positive, 15,087 (17\%) as negative, and $45,418(51 \%)$ as neutral/irrelevant.

During analysis of the manifest content of viewers' comments, three themes emerged. Comments were philosophical, relating to the ethics of cheating; comments were instructional, expressing personal methods of cheating; and comments were testimonial, reporting successful implementation of the cheating techniques described in the videos.

Viewers that posted positive philosophical comments tried to ethically justify the act of cheating. One viewer even posted Albert Einstein's famous quote "Imagination is more important than knowledge" as a comment to defend the processes of creating innovative cheating techniques instead of studying. Other viewers wrote the following selected comments:

I think that cheating is ok, depending on the cicumstances. If you just don't want to do any work at all, [then] you deserve to get caught. But if you NEED to cheat, [then] you should.

...studying doesn't guarantee that you'll be a better person or that you will have a successful future or anything, $i$ had friend who was straight $A$ in univesity and now he works as a teacher in a high school (what a job right? and that's his only job) and also another friend who couldn't even finish high school and now he owns a successful restaurant in Sweden.

Positive comments provided further instruction for cheating methods not described in the original video. The following comments reflect students' personal methods of cheating, the first being a modification to the method for lengthening a paper by changing font sizes of periods:

you should also change the size of the spaces using the same technique. this will also be barely noticeable but also lengthen your document by ALOT!

i prepare a small paper with the answers, put it in my shoe so it will be sticking out a litle bit, cover the visible part of the paper with my pants, and whenever $i$ need it , i simply pretend that im scraching my leg and i pull it out.

i right my answers on the side of my middle/ring finger, $i$ can just squeeze 2 of my fingers together and its not noticeable.

I go to a private school I put notes behind my tie lulz.

Positive viewer-posted comments also included testimonials about using the cheating methods described in the videos:

OMG replaced all my periods and commas, and got an 11 page paper up to 12 and 1/4!!! thanks sooooo much for this helpful vid.

I actually used this trick in french and $i$ usualy get $C$ all the time but I got a B ON THIS ONE THANKS!! 
Negative comments were often philosophical in terms of the ethics of cheating and were also critical of the amount of time and energy that students spend in order to cheat. In terms of negative philosophical comments, viewers criticised choosing to cheat instead of studying:

Is it just me, or does it seem like nobody wants to do things the right way? Why is it so difficult to simply learn the material? I don't know if the people that do this realize that cheating in college can result in immediate expulsion, meaning thousands of dollars lost.

I never cheated, worked my butt off, got a degree, and am relatively successful. If you cheat through high school or college, you'll cheat the rest of your life, and be worth nothing.

When tests are hard, you don't cheat, you study harder. I have failed tests before, but I have never cheated. If you cheat you're only cheating yourself. You have robbed yourself of learning something that could be useful to yourself. If you cheat you only become better at cheating.

Negative comments were also critical of the effort that students put into cheating instead of using that same effort to study:

If students would spend as much time studying as developing these stupid [cheating] techniques, they'd have no problems.

\section{Discussion}

\section{Methods of cheating}

The sample of instructional videos described methods for cheating on exams, homework and writing assignments. High technical cheating methods used some sort of modern technology to aid in the cheating process. Low technical cheating methods did not require the aid of modern technology. Findings suggest that most videos instructed viewers how to cheat on exams.

\section{Popularity of videos}

There is a substantial presence of instructional cheating videos on YouTube. These videos have become popular throughout several nations and appear, based on user comments, to be well received by viewers. Findings suggest that each instructional cheating video on YouTube is watched frequently and receive nearly twice the amount of positive viewer-posted comments compared to negative viewer-posted comments.

\section{Demographics of those who post and view videos}

Results of this study appear to support previous research findings that male students are more likely to cheat than female students (McCabe \& Trevino, 1997). The vast majority of those who post and those who view the videos included in this study were male. These results may be a reflection of the disproportion of cheating behaviours between male and female students. Viewers were within the typical ages of those who attend middle school, high school and college, suggesting that cheating is a more interesting or important topic for traditional-aged students than people of other ages. 


\section{Opinions of viewers}

The existence of testimonial-based positive comments suggests that the videos have not only educated students about methods of cheating, but have also inspired students to put these methods into practice. Positive viewer-posted comments may also indicate that YouTube has become an online forum for students in several nations to share cheating methods and to encourage each other to be dishonest in scholarly activities.

\section{Limitations}

We acknowledge limitations to this study. First, it is possible that the search terms used to locate videos may not have located all instructional videos concerning cheating in academics. Consequently, it is possible that the study's results may not be representative of all instructional cheating videos on YouTube. Second, viewer statistics data available on YouTube describes only registered YouTube members. Therefore, the findings presented in this paper do not represent all viewers and number of views, suggesting that our results are an underestimation of the popularity of these videos. Third, the search for videos related to cheating on YouTube resulted in videos that were presented in the English language only, indicating that those responsible for posting and viewing these videos are proficient in the English language. This limited our ability to claim that cheating videos on YouTube is a global phenomenon. However, these videos were viewed by people residing throughout the world, suggesting that cheating videos on YouTube is no doubt an international concern. Finally, those who view a video that describes methods of cheating may do so out of mere curiosity or entertainment without intending to implement the method of cheating described in the video. The increase in the number of views during the study's timeline does not necessarily reflect an increase in the implementation of cheating methods.

\section{Recommendations for future practice}

Based on study findings, it is recommended that educators increase their awareness of the cheating methods detailed in the videos. It may be useful for educators at all levels to use YouTube as a resource to help stay abreast of cheating methods among students. Successful cheating depends on instructor ignorance. Educators who are aware of popular cheating methods are better prepared to thwart them. While YouTube does not represent an exhaustive inventory of cheating techniques, it appears to be one forum for strategy sharing. Seeking out and viewing these videos may help educators fend off cheating by their students.

The vast majority of both high tech and low tech methods of cheating described in the videos instructed viewers how to cheat on exams. This finding suggests that assessing student knowledge through exams increases opportunities for students to cheat. Therefore, the authors recommend that educators implement more varied methods of assessment in their classrooms to reduce the opportunity for students to cheat.

\section{References}

Alexa. (2011). The top 500 sites on the web. Retrieved January 3, 2011, from http:// www.alexa.com/topsites.

Brimble, M., \& Stevenson-Clarke, P. (2005). Perceptions of the prevalence and seriousness of academic dishonesty in Australian universities. The Australian Educational Researcher, 32(3), 19-44.

Foster, A. (2008, July 11). Students show how to cheat via YouTube. The Chronicle of Higher Education. Retrieved December 10, 2010, from http://chronicle.com/ blogs/wiredcampus/students show-how-to-cheat-via-youtube/4088

Franklyn-Stokes, A., \& Newstead, S. E. (1995). Undergraduate cheating: Who does what and why? Studies in Higher Education, 20(2), 39-52. 
Harper, M. G. (2006). High tech cheating. Nurse Education Today, 26(8), 672-679.

Hrabak, M., Vujaklija, A., Vodopivec, I., Hren, D., Marušić, M., \& Marušić, A. (2004). Academic misconduct among medical students in a post-communist country. Medical Education, 38(3), 276-285.

Kennedy, K., Nowak, S., Raghuraman, R., Thomas, J., \& Davis, S. (2000). Academic dishonesty and distance learning: Student and faculty views. College Student Journal, 34(2), 309-314.

Lathrop, A., \& Foss, K. (2000). Student cheating and plagiarism in the internet era: A wake up call. Englewood, CO: Libraries Unlimited.

Lin, C. S., \& Wen, L. M. (2007). Academic dishonesty in higher education - a nationwide study in Taiwan. Higher Education, 54(1), 85-97.

Lupton, R. A., Chapman, K. J., \& Weiss, J. E. (2000). A cross-national exploration of business students' attitudes, perceptions, and tendencies toward academic dishonesty. Journal of Education for Business, 75(4), 231-235.

McCabe, D. L., \& Treviño, L. K. (1993). Academic dishonesty: Honor codes and other contextual influences. Journal of Higher Education, 64(5), 522-538.

McCabe, D. L., \& Treviño, L. K. (1997). Individual and contextual influences on academic dishonesty: A multicampus investigation. Research in Higher Education, 38(3), 379-396.

McCabe, D. L., Treviño, L. K., \& Butterfield, K. D. (2001). Cheating in academic institutions: A decade of research. Ethics \& Behavior, 11(3), 219-232.

Orsini, M. M., \& Gringle, M. R. (2009, February). Cheating on exams with modern technologies in $21^{\text {st }}$ century college and university classrooms. Presented at the annual Lilly Conference on College and University Teaching, Greensboro, NC.

Schmelkin, L. P., Gilbert, K., Spencer, K. J., Pincus, H. S., \& Silva, R. (2008). A multidimensional scaling of college students' perceptions of academic dishonesty. The Journal of Higher Education, 79(5), 587-607.

Szabo, A., \& Underwood, J. (2004). Cybercheats: Is information and communication technology fuelling academic dishonesty? Active Learning in Higher Education, 5 (2), 180-199.

YouTube. (2011a). About YouTube. Retrieved January 3, 2011, from http:// www.youtube.com/t/about

YouTube. (2011b). YouTube Essentials. Retrieved January 3, 2011, from

http://www.youtube.com/t/about essentials

YouTube. (2011c). YouTube fact sheet: Traffic and stats. Retrieved January 3, 2011, from http://www.youtube.com/t/fact sheet

\section{About the authors}

Christopher M. Seitz is currently a Doctor of Public Health candidate in the Department of Public Health Education at the University of North Carolina in Greensboro. He has taught several college courses available for the general student body as well as for college student-athletes specifically. His interests in research involve tobacco control policies, college student misperceptions regarding substance use, and the Photovoice process.

Dr. Muhsin Michael Orsini has experience teaching and learning in a variety of contexts involving diverse subjects, settings and populations. He is currently the Director of Undergraduate Programs and Assistant Professor in the Department of Public Health Education at the University of North Carolina in Greensboro. Prior to earning his doctorate, he served as a Chaplain Assistant in the US Army, worked as an Information Specialist at the National STD Hotline, taught high school mathematics and social studies, and worked as an Evaluation Specialist at UNC Chapel Hill. His research interests are focused on program evaluation, health education, curriculum and instruction. 
Meredith R. Gringle is a Doctor of Public Health student in the Department of Public Health Education, University of North Carolina in Greensboro. Meredith has extensive experience teaching at the college level. Her general areas of interest include pregnancy/childbirth, families, gender dynamics, hegemonic masculinity, and the relationship between masculinity and college athletes' attitudes towards injury. 